\title{
Queering I Am Not Your Negro: or Why We Need James Baldwin More Than Ever
}

\author{
Robert J. Corber Trinity College
}

\begin{abstract}
The author reviews Raoul Peck's 2016 film, I Am Not Your Negro, finding it a remarkable achievement as a documentary that breaks with cinematic conventions and emphasizes the importance of listening as much as looking. The director has singled out Baldwin as the writer whose work spoke most directly to his own identity and experience during his peripatetic childhood in Haiti and Africa, and in I Am Not Your Negro, Peck aims to ensure that Baldwin's words will have a similar effect on audiences. However, even as it succeeds in reanimating Baldwin's voice for a new political era, I Am Not Your Negro inadvertently exposes the difficulty of fully capturing or honoring the writer's complex legacy. As scholars have long noted, interest in Baldwin's life and work tends to divide along racial and sexual lines, and Peck's documentary is no exception. The filmmaker privileges Baldwin's blackness over his queerness by overlooking the parts of The Devil Finds Work and No Name in the Street in which the writer's queerness figures prominently.
\end{abstract}

Keywords: I Am Not Your Negro, Raoul Peck, The Devil Finds Work, James Baldwin, sexuality, blackness, queer, movies

In The Devil Finds Work (1976), a masterpiece of film criticism in which he explored the racial politics of Hollywood cinema starting with the Great Depression, James Baldwin bemoaned the difficulties screenwriters faced when tasked with adapting a written text for the movies. Drawing on his own experience working on the screen version of The Autobiography of Malcolm X in the late 1960s, a project he eventually abandoned when Columbia Pictures insisted on making several cuts to his screenplay, he observed that "the only way to translate the written word to the cinema involves doing considerable violence to the written word, to the extent, indeed, of forgetting the written word." Baldwin traced this violence to the very

James Baldwin Review, Volume 3, 2017 (c) The Authors. Published by Manchester University Press and The University of Manchester Library 
nature of Hollywood cinema, which, in subordinating sound to image, privileged looking over listening. "A film is meant to be seen," Baldwin explained, "and, ideally, the less a film talks, the better" (p. 112). But despite the filmmaker's need to "forget" the written word, he or she still had an obligation "to remain faithful to the intention, and the vision, of the original form," an obligation that entailed "making very subtle and difficult choices" (p. 112). These choices, Baldwin asserted, amounted to a "willed and deliberate act" (p. 112) that revealed the filmmaker's racial politics. Although the filmmaker may not have fully understood or been conscious of those politics, they nevertheless determined the choices that he or she made. According to Baldwin, audiences saw the film they were intended to see, and as a consequence critics could not dismiss an adaptation as weak or failed without accounting for the filmmaker's motives in altering or misrepresenting the original text.

These reflections laid the groundwork for Baldwin's searing critique of the 1972 screen version of Billie Holiday's autobiography, Lady Sings the Blues, which starred Diana Ross and Billie Dee Williams. For Baldwin, the film not only did considerable violence to Holiday's written word, but also distorted her intentions by sanitizing her unembellished account of her struggles as a black woman, struggles that included grinding poverty, violent sexual assault, exploitation as a vocalist, and persistent discrimination. Baldwin objected in particular to the movie's depiction of the circumstances that supposedly inspired her to perform what eventually became her signature song, "Strange Fruit." In the autobiography, Holiday recounts that when she first read Abel Meeropol's poem protesting the terroristic lynchings of southern black men, she immediately thought of her father, a disabled veteran who was denied adequate medical care for the injuries he sustained during the First World War and eventually died in the Jim Crow ward of a Dallas hospital. For Holiday, the poem captured the forces responsible for her father's death, even though he was not the victim of a lynching. ${ }^{2}$ In the film, by contrast, Holiday played by Ross decides to perform "Strange Fruit" after stumbling upon a group of grieving black people gathered below the castrated body of a black man hanging from a tree while on tour in the South. Baldwin rightly asserted that this scene is "as remote as an Indian massacre, occurring in the same landscape, and eliciting the same response: a mixture of pious horror, and gratified reassurance" (p. 114). He attributed the film's revision of this and similar episodes in the autobiography to the threat Holiday's honesty in recounting her experiences of racial and patriarchal oppression posed to the status quo. "That victim who is able to articulate the situation of the victim," he observes, "has ceased to be a victim: he or she has become a threat" (p. 115). In forcefully speaking out against racial and sexual injustice, Holiday demonstrated her agency as a black woman and thereby refuted the racist stereotypes of black female identity inscribed in white supremacy.

In his powerfully evocative new documentary I Am Not Your Negro, Raoul Peck has solved the problem of adaptation Baldwin so astutely identified in his critique of the film version of Lady Sings the Blues. The documentary succeeds 
in translating the writer's words to the silver screen without inflicting violence on them. Perhaps Peck's most remarkable achievement in the documentary is in breaking with cinematic conventions and emphasizing the importance of listening as much as looking. The director has singled out Baldwin as the writer whose work spoke most directly to his own identity and experience during his peripatetic childhood in Haiti and Africa. "All I knew or had learned through instinct or through experience," he recalled, "Baldwin gave a name to and a shape." Indeed, Baldwin taught him how to articulate his own history and experience of racial oppression: "Baldwin gave me a voice, gave me the words, gave me the rhetoric."4 In I Am Not Your Negro, Peck aims to ensure that Baldwin's words will have a similar effect on audiences. He has culled the script from the writer's published and unpublished work, which actor Samuel L. Jackson reads in an almost deadpan voice as images of civil rights protests past and present, many of which will be familiar to audiences, flash on the screen. ${ }^{5}$ Jackson's subdued tone provides a striking contrast to the animated voice we hear in the archival footage of interviews and lectures that Peck has incorporated into the documentary in which the writer himself speaks. This contrast seems intended to ensure that audiences do not become distracted by Jackson's ventriloquism but instead remain focused on Baldwin's language. That language not only gives new meaning and urgency to the still photographs of Black Lives Matter demonstrations included in the documentary, but also transforms our understanding of the images of the Civil Rights movement of the 1950s and 1960s with which they are interwoven. Peck has stated that he never intended the documentary to be a "historical piece" but that his goal was "to bring [Baldwin's] work to the forefront again" by staging a dialogue between past and present. ${ }^{6}$ In recalibrating the relationship between sound and image in the cinema, Peck showcases Baldwin's enduring power to articulate the issue of racial oppression in American society.

Also remarkable is Peck's success in translating the innovative form of Baldwin's essays into cinematic terms. Baldwin was hailed as a master of the essay form early in his career, a writer who stretched the form's boundaries and opened up its possibilities. Blending autobiography, cultural critique, and historical analysis, his essays cross genres and resist easy definition. ${ }^{7}$ Despite the rigor and coherence of his examination of pressing social and political issues, Baldwin never develops his arguments chronologically or in a linear fashion but instead moves readily from past to present and back again, thereby conveying his belief in history's inescapable influence over individual experience. In the final segment of I Am Not Your Negro, Jackson reads in voice-over Baldwin's famous warning about the consequences of historical amnesia: "History is not the past. It is the present. We carry our history with us. We are our history. If we pretend otherwise, we literally are criminals." 8 Particularly in Baldwin's later, more loosely structured and digressive essays such as No Name in the Street (1972) and The Devil Finds Work-from which Peck has stitched together much of the documentary's script-personal recollection lays the foundation for critical reflection which in turn leads to more personal recollection. Peck similarly engages in formal innovation, and like Baldwin's essays, 
I Am Not Your Negro defies classification. Unlike most other documentaries, it includes no interviews with talking heads or biographical information about its subject; instead, audiences must glean their own understanding of Baldwin's life and work from Jackson's voice-over narration. Moreover, although Peck has divided the documentary into segments or chapters, each with its own theme or topic, it is as loosely structured as Baldwin's essays, and like them moves backward and forward in time, interlacing archival footage from the 1950s and 1960s with more recent images.

Even as it succeeds in reanimating Baldwin's voice for a new political era, I Am Not Your Negro inadvertently exposes the difficulty of fully capturing or honoring the writer's complex legacy. As scholars have long noted, interest in Baldwin's life and work tends to divide along racial and sexual lines, and Peck's documentary is no exception. ${ }^{9}$ The filmmaker privileges Baldwin's blackness over his queerness by overlooking the parts of The Devil Finds Work and No Name in the Street in which the writer's queerness figures prominently. I Am Not Your Negro mentions Baldwin's homosexuality only once, when it quotes an FBI memorandum. To the sound of a typewriter, the following words spelled out in white letters on a black background materialize on the screen: "It has been heard that Baldwin may be an $[s i c]$ homosexual and he appeared as if he may be one." Here Peck seems less interested in drawing attention to Baldwin's perverse sexuality and its role in his development as a writer than in emphasizing the threat the authorities believed his writings and activism posed to the established order. But Baldwin's life and work cannot be understood apart from both his racial and his sexual identities. Baldwin's homosexuality not only informed his eloquence as a writer, one of Peck's reasons for admiring him, but also precipitated the negative reception of his work following the emergence of the black power movement in the late 1960s. It also underlay his understanding of the relationship between white supremacy and the construction of masculinity in American society. Peck's selective reading of Baldwin's essays suggests that he does not fully grasp why they are as politically relevant today as when they were first published.

\section{Baldwin's Queer Childhood}

Peck's privileging of Baldwin's blackness is nowhere more apparent than in his use of The Devil Finds Work. In a recent interview, Peck recounts that it was not until his family fled Haiti and settled in the Congo that he became aware of the extent to which Hollywood misrepresented social reality. The Africa he experienced had nothing in common with the one depicted in the movies he had seen in Haiti and that had led him to believe that African men and women were "savages dancing in the forest." 10 As a result, Peck began to realize that the medium he had fallen in love with as a child was "more dangerous than it looks, that it is not so innocent." ${ }^{11}$ Baldwin elucidated the nature of this danger by revealing to him "what was the content of films besides just a story and great actors, that film is also ideology." ${ }^{2}$ It is hardly surprising, then, that when Peck addresses 
Baldwin's complicated relationship to Hollywood cinema in I Am Not Your Negro he turns to The Devil Finds Work. Much of Baldwin's analysis there does indeed suggest that movies are "ideological" in the sense implied by Peck, namely, that they elicit the audience's consent to the status quo by naturalizing existing social arrangements. This is certainly true of Baldwin's discussions of The Defiant Ones (1957), In the Heat of the Night (1967), and Guess Who's Coming to Dinner (1967). Although these films were widely praised for their supposedly liberal racial politics at the time of their release, Baldwin showed that they further entrenched unequal relations between blacks and whites. Moreover, many of Baldwin's anecdotes about his childhood reactions to the movies indicate a pattern of enchantment and betrayal similar to the one described by Peck. In his 1965 debate with William F. Buckley at Cambridge University, for example, footage of which Peck has included in I Am Not Your Negro, the writer revealed that "it comes as a great shock around the age of five, or six, or seven to discover that Cary Cooper killing off the Indians when you were rooting for Gary Cooper, that the Indians were you." But overall Baldwin's recollections of his childhood encounters with the movies in The Devil Finds Work and elsewhere point to a much more complicated understanding of the cinema and its effects on viewers than Peck's representation of them in his documentary suggests.

In "Congo Square," the first section of The Devil Finds Work, Baldwin traces, albeit obliquely, the development of his queer identity. He recalls that when he was a child, everyone regarded him as “'strange,' including my poor mother, who didn't, however, beat me for it” (p. 8). His exposure to Hollywood cinema deeply informed this aspect of his identity. It nurtured cross-racial and cross-gendered identifications that enabled him to reject the patriarchal authority his disapproving stepfather exemplified. As a child, Baldwin never questioned his stepfather's devastating judgment that he was "the ugliest boy he had ever seen" (p. 6), a judgment that would have a "decidedly terrifying effect" (p. 7) on his life, until he encountered Bette Davis on screen in the 1932 gangster movie, 20,000 Years in Sing Sing. Davis had the same "frog eyes" (p. 6) as he did, the aspect of his features his stepfather disliked most because they reminded him of Baldwin's mother, and she moved "just like a nigger" (p. 7). ${ }^{13}$ Liberating him from his stepfather's overbearing influence, this discovery proved enormously empowering for Baldwin: "I had caught my [stepfather], not in a lie, but in an infirmity" (p. 7). Despite her perceived ugliness, Davis was one of Hollywood's most successful stars, and Baldwin now realized that like her he had the capacity to forge his defects "into weapons" (p. 8). It was at the movies, then, that Baldwin became determined to transform his queer identity from a failing his stepfather and others tried to beat out of him into a powerful resource. He remarks that it was while attending the movies on Saturday afternoons with his beloved teacher Orilla "Bill" Miller that he made his "first conscious calculation as to how to go about defeating the world's intentions" (p. 9) for him and his siblings.

Baldwin's childhood fascination with another iconic star from Hollywood's golden age, Sylvia Sidney, was no less Oedipally charged than his identification 
with Davis. Sidney was the only female star who reminded Baldwin of a black woman, "which is to say that she was the only [one] who reminded me of reality" (p. 21). He fantasized that he and Sidney shared a personal connection-"she seemed to know something I knew" (p. 22) - and he always found her acting believable, regardless of how trite or uninspired her movies were. In her movies, her characters were "always beaten up, victimized, weeping" (p. 21) but they were never afraid to confront the police who had abused them. Baldwin's attachment to Sidney provides another example of how the movies instilled in him a disidentification with patriarchal authority. Because of the type of movie she appeared in, Sidney reminded him of Bill Miller, the white elementary school teacher who took him under her wing. Like Sidney's characters, Miller was not afraid to stand up to "hostile cops" (p. 21) who treated her like a "nigger" (p. 6) because of her attachment to her black students. Baldwin's association of Miller and Sidney is revealing. Baldwin's stepfather disliked and distrusted Miller, not least because she was the one who had introduced young James to the pleasures of the cinema, and he held her partly responsible for his stepson's "strangeness." Miller encouraged Baldwin's love of books, took him to the movies and the theater, and discussed current events with him, all of which his stepfather deeply resented. But despite his stepfather's disapproval, Baldwin remained deeply loyal to her, and he maintained their friendship until he entered the pulpit when he was in his teens and she expressed her disappointment in him. In disobeying his stepfather, Baldwin followed the example provided by both Miller and Sidney in their defiance of patriarchal power as represented by the police.

Baldwin's queer identification with movie stars like Davis and Sidney existed in tension with his belief that the cinema functioned ideologically. He realized that stars had the capacity to disrupt Hollywood's attempts to "brainwash" audiences into accepting the world as it was by interrupting the viewer's absorption in the movies' narrative flow. ${ }^{14}$ In the process, stars opened up a critical distance between the viewer and the stories unfolding on the screen. ${ }^{15}$ For Baldwin, Davis's performance as a spoiled southern white woman guilty of murder in the 1942 screen adaptation of Eleanor Glasgow's novel In This Our Life exemplified this capacity. He especially admired Davis's acting in the scene in which she visits the black chauffeur who has been accused of the murder but has steadfastly maintained his innocence and tries to seduce him into altering his testimony. Baldwin argues that Davis's performance was so "ruthlessly accurate" that it succeeded in "exposing and shattering" (p. 60) the film's deeply problematic racial politics, which aimed to reassure audiences that white supremacy had disappeared from the South. Robert Walker's role as a wayward son under investigation by the FBI for his subversive political beliefs in the 1952 anti-communist film, My Son John, provided Baldwin with a somewhat different example of the way in which a star could unsettle a movie's political agenda. Rather than being "ruthlessly accurate," Walker's performance bordered on camp. It amounted to a "gleefully vicious parody" (p. 90) that inadvertently exposed the suffocating provincialism of Cold War American society. In Baldwin's view, Walker played the part of the dissolute 
renegade son "for all it [was] worth, absolutely heartless and hilarious, acting out all of his mother's terrors, including, and especially, the role of the flaming faggot, which is his father's terror, too" (p. 91). As a result, the film inadvertently distanced audiences from the supposedly quintessential American values and attitudes it sought to uphold. Walker's exuberant performance showed that violating Cold War gender and sexual norms could be enormously empowering.

\section{Baldwin's Queer Relevance}

That Peck avoided addressing the more complicated aspects of Baldwin's relationship to Hollywood cinema in I Am Not Your Negro is hardly surprising. Baldwin himself tended to marginalize his homosexuality, especially after the radicalization of anti-racist struggle in the late 1960s, and he began to incorporate some of the Black Panther Party's masculinist rhetoric into his writing. For many readers, Baldwin's homosexuality, supposedly rendered visible by his expressive mannerisms, disqualified him as a spokesman for the Civil Rights movement. For example, around the time of the publication in 1963 of The Fire Next Time, perhaps his most famous essay on racial inequality, an article in Time described him as a "nervous, slight, almost fragile figure, filled with frets and fears" and declared that he was "not, by any stretch of the imagination, a Negro leader." ${ }^{16}$ Instead of disputing the assumption underlying this and similar criticisms of his work-that militancy and masculinity were interrelated-Baldwin began to embrace it. In an appallingly homophobic passage in No Name in the Street, arguably his most radical essay, in which as several critics have noted he appropriated the language of Third World Marxist critique, he defended Eldridge Cleaver, despite the venomous attack Cleaver had mounted on Baldwin in his controversial 1968 book Soul on Ice. ${ }^{17}$ Baldwin acknowledges that he was stung by the attack when he first read it, but he has since come to understand why the black revolutionary deemed it necessary: "I was confused in his mind with the unutterable debasement of the male-with all those faggots, punks, and sissies, the sight and sound of whom, in prison, must have made him vomit more than once." ${ }^{18}$ Here Baldwin came perilously close to endorsing Cleaver's view of homosexuality as a white man's disease that robbed black men of their manhood.

In adopting a more militant stance intended to appease his critics, Baldwin also tended to forget one of the most important lessons of his childhood encounters with the cinema, the importance of challenging patriarchal power. At times in his later essays, he implied that the most damaging aspect of white supremacy was its emasculation of black men and that the only way to remedy this injury was for them to gain access to patriarchal privilege. Black men supposedly could not reclaim their manhood until they fulfilled the breadwinner role fundamental to the definition of masculinity in American society. In a testy exchange with the poet Nikki Giovanni published in 1973, Baldwin claimed, "Look, if we're living in the same house and you're my wife or my woman, I have to be responsible for that house. If I'm not allowed to be responsible for that house, I'm no longer 
in my own eyes-it doesn't make any difference what you make think of me-in my own eyes I'm not a man." 19 An exasperated Giovanni responded, "I can get my own damn steak!" 20 Peck seems to agree with Baldwin, or at the very least he seems not to have grasped how problematic Baldwin's claim was. He has incorporated footage from Baldwin's 1968 appearance on The Dick Cavett Show into I Am Not Your Negro, in which he espoused a view of black male injury similar to the one above: "But what I was discussing was not that problem, really. I was discussing the difficulties, the obstacles, the very real danger of death thrown up by the society when a Negro, when a black man attempts to become a man." Perhaps more significant is the scene from the 1961 screen version of Lorraine Hansberry's award-winning play A Raisin in the Sun that Peck has chosen to include in the documentary. In the scene, Sidney Poitier's character rages at the world for preventing him from fulfilling his role as head of his household: "All I want is to make a future for this family. All I want is to be able to stand in front of my boy like my father never was able to do to me."

Even in the interviews and essays that Peck draws on most in I Am Not Your Negro, Baldwin's views of homosexuality and black masculinity were more contradictory than the documentary implies. Scholars often cite Baldwin's 1982 interview with Richard Goldstein, published in the Village Voice near the end of his life, as evidence of the increasingly hard line he supposedly took on issues of gender and sexuality. ${ }^{21}$ In the interview he revealed his lack of identification with gay culture: “The word 'gay' has always rubbed me the wrong way. I never understood exactly what is meant by it ... I simply feel it's a world that has very little to do with me, with where I did my growing up." 22 He also seemed to suggest that racism was a more serious problem in American society than homophobia: "The sexual question comes after the question of color; it's simply one more aspect of the danger in which all black people live" (p. 180). But Baldwin's views on homosexuality were not always easy to pin down and could slip in and out of focus. Indeed, many of his comments elsewhere in the interview with Goldstein not only clarified his refusal to embrace the struggle for gay rights but also anticipated queer of color critique. If Baldwin distanced himself from the gay and lesbian movement, he did so because of his perception of its racial politics. For him, the majority of the white men and women who participated in the movement did so because their homosexuality prevented them from taking full advantage of their racial privilege, which left them feeling betrayed by their society; otherwise they would also have participated in the struggle for racial equality: "Their reaction seems to me in direct proportion to the sense of feeling cheated of the advantages that accrue to white people in a white society" (p. 180). Despite this criticism of gay and lesbian activists, however, Baldwin welcomed their attempts to improve homosexuals' lives by eradicating homophobia: "And if the so-called gay movement can cause men and women, boys and girls, to come to some kind of terms more speedily and with less pain [than my generation], then that's a very great advance" (pp. 183-4).

Baldwin's widely admired eloquence as a writer also conflicted with his problematic assertions about homosexuality and black masculinity in his later work. 
As several scholars have noted, with its intricate layering of personal experience and critical reflection, his prose inscribed his queer identity. ${ }^{23}$ In Notes of a Native Son, his first essay collection published in 1955, Baldwin explained that he derived his distinctive voice from "the rhetoric of the store-front church, something ironic and violent and perpetually understated in Negro speech-and something of Dickens' love for bravura." ${ }^{4}$ But he also modeled his prose on Henry James, a writer dismissed by critics when Baldwin was coming of age intellectually in the 1930s and 1940s for supposedly belonging to the "genteel tradition" of American letters. ${ }^{25}$ Instead, these critics championed the spare, unadorned modernism of Ernest Hemingway, popularized by hardboiled crime writers like James M. Cain and Raymond Chandler. As Cheryl Wall usefully reminds us in her perceptive discussion of Baldwin's language, the "Hemingway" version of modernism incorporated a patriarchal construction of masculinity. ${ }^{26}$ In choosing James over these other writers as his model, Baldwin disavowed this construction, which he blamed for the homosexual's traumatic persecution in American society. In the interview with Goldstein, Baldwin suggested that men had invented the category of the faggot to protect themselves from the waywardness of their own desires. Because of the norms governing masculinity, men could never express or act on their homoerotic impulses without undermining their claims to manhood; therefore they projected their sexual fantasies onto other men. Baldwin remarked that the figure of the faggot allowed men "to act out a sexual fantasy on the body of another man and not take any responsibility for it" (pp. 178-9), and he exhorted the homosexual to recognize "that he is a sexual target for other men, and that is why he is despised, and why he is called a faggot" (p. 179). Thus Baldwin's prose style signified a repudiation of the dominant form of masculinity even in the passages in his later work where he proposed that black men needed access to patriarchal privilege, or where he indulged in homophobic stereotypes.

It is partly because of these aspects of Baldwin's work that we need his voice now more than ever. Perhaps inspired by the writer's extensive discussion of police brutality in the final section of No Name in the Street, Peck returns again and again in I Am Not Your Negro to the recent spate of police shootings of unarmed black men that have given rise to the Black Lives Matter movement. ${ }^{27}$ In one of the documentary's most poignant sequences, still photographs of the victims of those shootings appear on screen in chronological order, starting with Trayvon Martin. Coupled with Jackson's reading of one of Baldwin's most fiery indictments of American society, the sequence drives home how little has changed for African Americans since the 1950s and 1960s and grounds the continuing relevance of his prophetic voice in the persistence of white supremacy.

Given the recent white nationalist turn in American politics, this approach to Baldwin's life and work seems more than justified. President Donald Trump's pledge to make "America Great Again" seems to entail making it white again. As countless polls have shown, Trump was carried into the White House on a wave of anti-immigrant sentiment directed at people of color and his promise to "build a wall." But this triumph of white nationalism is not the only danger Trump's rise to 
power signals. From Vice President Mike Pence's constant references to Trump's "broad shoulders" in a campaign to defeat the first female presidential candidate nominated by a major party, to campaign advisor Steve Bannon's homophobic rant that the "liberal" media vilify conservative female politicians because they are not a "bunch of dykes that came from the Seven Sisters schools," Trump's election has vindicated the toxic masculinity that permeates American society and that feminist and queer activists have made only limited headway in challenging. ${ }^{28}$ Baldwin understood the intimate relationship between this form of masculinity and white supremacy. In the interview with Goldstein, he maintained that "the sexual question and the racial question are entwined, you know. If Americans can mature on the level of racism, then they have to mature on the level of sexuality" (p. 178). It is because of this recognition that Baldwin can impart to us the language we need, not only for speaking out against racial injustice, as Peck so powerfully communicates in I Am Not Your Negro, but also for confronting patriarchal power and homophobia in the age of Trump.

\section{Notes}

1 James Baldwin, The Devil Finds Work (1976) (New York, Vintage Books, 2011), pp. 111-12. All subsequent quotations are taken from this edition. Page numbers are given in parentheses in the text. Spike Lee incorporated elements of Baldwin's screenplay, One Day When I Was Lost, into his 1992 film Malcolm X starring Denzel Washington.

2 Billie Holiday and William F. Duffy, Lady Sings the Blues (1956) (London, Penguin Press, 1992), p. 84.

3 James Baldwin, I Am Not Your Negro: A Major Motion Picture Directed by Raoul Peck (New York, Vintage Books, 2017), p. xii.

4 Ibid.

5 Baldwin's sister and literary executor, Gloria Baldwin Karefa-Smart, gave the director unprecedented access to his papers, including thirty pages of notes for a never completed book about Medgar Evers, Martin Luther King, and Malcolm X entitled Remember This House, which Peck uses as the point of departure for his documentary. See Baldwin, I Am Not Your Negro, pp. xiii-xv.

6 Quoted in Lanre Bakare, "The Fire this Time-The Legacy of James Baldwin," Guardian, 15 February 2017, www.theguardian.com/books/2017/feb/15/the-fire-thistime-legacy-of-james-baldwin (accessed 23 June 2017).

7 For a more detailed discussion of this aspect of Baldwin's work, see Douglas Field, All Those Strangers: The Art and Lives of James Baldwin (Oxford, Oxford University Press, 2015), pp. 1-11, and Cheryl A. Wall, "Stranger at Home: James Baldwin on What It Means to Be an American," in Cora Kaplan and Bill Schwarz (eds.), James Baldwin: America and Beyond (Ann Arbor, MI, University of Michigan Press, 2011), pp. 35-52.

8 For a particularly interesting discussion of the role of history in both the documentary and Baldwin's work, see Ismail Muhammad, "The Misunderstood Ghost of James Baldwin,” Slate, 15 February 2017, www.slate.com/articles/arts/books/2017/02/how_ critics_have_misunderstood_james_baldwin_s_influence_on_today_s_great.html (accessed 23 June 2017). 
9 For a discussion of this aspect of critical studies of Baldwin's work, see Cora Kaplan and Bill Schwarz, "Introduction: America and Beyond," in Kaplan and Schwarz (eds.), James Baldwin, pp. 6-7, and Field, All Those Strangers, pp. 8-9.

10 Terry Gross, "Director Raoul Peck: James Baldwin Was 'Speaking Directly To Me,"” Fresh Air, NPR, podcast audio, 14 February 2017, www.npr.org/2017/02/14/515196224/ director-raoul-peck-james-baldwin-was-speaking-directly-to-me (accessed 23 June 2017).

11 Ibid.

12 Ibid.

13 It is worth noting that Baldwin's expressive use of his cigarette in the clips of his appearances on The Dick Cavett Show and elsewhere included in the documentary bear a striking resemblance to Bette Davis's expressive use of her own cigarette on- and off-screen, and indicate that his childhood identification with her carried over into his adulthood.

14 "Brainwashing" is the term Baldwin uses to describe the media's impact on the American population in No Name in the Street, but it is important to point out that his analysis of Hollywood cinema was much more nuanced in The Devil Finds Work published four years later. See James Baldwin, No Name in the Street (New York, Vintage Books, 2007), p. 160.

15 Here Baldwin anticipated by almost two decades one of the most important insights of feminist film theory. See, for example, Miriam Hansen, "Pleasure, Ambivalence, and Identification: Valentino and Female Spectatorship," in Christine Gledhill (ed.), Stardom: Industry of Desire (New York, Routledge, 1991), pp. 259-82.

16 Quoted in Field, All Those Strangers, p. 67.

17 For a detailed discussion of the radicalization of Baldwin's voice, see Kaplan and Schwarz, "Introduction," pp. 11-18, and Field, All Those Strangers, pp. 72-81. See also Wall, "Stranger at Home," pp. 42-8. Wall challenges the perception that late essays like No Name in the Street marked Baldwin's decline as a writer and argues persuasively for the importance of the shift in his voice from Jeremiah to Job.

18 Baldwin, No Name in the Street, pp. 171-2.

19 James Baldwin and Nikki Giovanni, A Dialogue (New York, Lippincott, 1973), p. 52.

20 Ibid., p. 55.

21 See, for example, Field, All Those Strangers, pp. 64-5.

22 Richard Goldstein, “'Go the Way Your Blood Beats': An Interview with James Baldwin," in Quincy Troupe (ed.), James Baldwin: The Legacy (New York, Simon and Schuster, 1989), p. 174. All subsequent citations are taken from this edition. Page numbers are given in parentheses in the text.

23 See, for example, Wall, "Stranger at Home," pp. 40-1.

24 James Baldwin, Notes of a Native Son (Boston, Beacon Press, 1984), p. 5. For a discussion of these different influences, see Wall, "Stranger at Home," pp. 39-41.

25 I discuss this aspect of Baldwin's work in more detail in Robert J. Corber, Homosexuality in Cold War America: Resistance and the Crisis of Masculinity (Durham, N.C., Duke University Press, 1997), pp. 160-90.

26 Wall, "Stranger at Home," p. 41. For an important discussion of Hemingway's problematic gender politics, see Linda Martin Wagner, Ernest Hemingway: A Literary Life (London, Palgrave Macmillan, 2007). For a discussion of hardboiled crime fiction, see Christopher Breu, Hardboiled Masculinities (Minneapolis, MN, University of Minnesota Press, 2005), and Sean McCann, Gumshoe America: Hardboiled Crime 
Fiction and the Rise and Fall of New Deal Liberalism (Durham, N.C., Duke University Press, 2000).

27 Baldwin, No Name in the Street, pp. 159-69.

28 Lucy Clark-Billings, "Donald Trump's Right-Hand Man Steve Bannon and His History of Attacks Against Women," Newsweek, 15 November 2016, www.newsweek.com/ donald-trumps-chief-strategist-steve-bannon-and-his-history-attacks-against-521240 (accessed 12 March 2017). Bannon did not mention Hillary Clinton but he did not need to. She attended Wellesley, one of those Seven Sisters schools, and rumors have long circulated on the right that she is lesbian.

\section{Works Cited}

Bakare, Lanre, "The Fire This Time-The Legacy of James Baldwin," Guardian, 15 February 2017, www.theguardian.com/books/2017/feb/15/the-fire-this-time-legacy-of-james-bal dwin (accessed 23 June 2017).

Baldwin, James, The Devil Finds Work (1976) (New York, Vintage Books, 2011).

I Am Not Your Negro: A Major Motion Picture Directed by Raoul Peck (New York, Vintage Books, 2017).

- No Name in the Street (New York, Vintage Books, 2007).

- Notes of a Native Son (Boston, Beacon Press, 1984).

- and Nikki Giovanni, A Dialogue (New York, Lippincott, 1973).

Breu, Christopher, Hardboiled Masculinities (Minneapolis, MN, University of Minnesota Press, 2005).

Clark-Billings, Lucy, "Donald Trump's Right-Hand Man Steve Bannon and His History of Attacks Against Women," Newsweek, 15 November 2016, www.newsweek.com/ donald-trumps-chief-strategist-steve-bannon-and-his-history-attacks-against-521240 (accessed 12 March 2017).

Corber, Robert J., Homosexuality in Cold War America: Resistance and the Crisis of Masculinity (Durham, N.C., Duke University Press, 1997).

Field, Douglas, All Those Strangers: The Art and Lives of James Baldwin (Oxford, Oxford University Press, 2015).

Goldstein, Richard, “'Go the Way Your Blood Beats': An Interview with James Baldwin,” in Quincy Troupe (ed.), James Baldwin: The Legacy (New York, Simon and Schuster, 1989), pp. 173-85.

Gledhill, Christine (ed.), Stardom: Industry of Desire (New York, Routledge, 1991).

Gross, Terry, "Director Raoul Peck: James Baldwin Was 'Speaking Directly to Me,'” Fresh Air, NPR, podcast audio, 14 February 2017, www.npr.org/2017/02/14/515196224/ director-raoul-peck-james-baldwin-was-speaking-directly-to-me (accessed 23 June 2017).

Hansen, Miriam, "Pleasure, Ambivalence, and Identification: Valentino and Female Spectatorship," in Christine Gledhill (ed.), Stardom: Industry of Desire (New York, Routledge, 1991), pp. 259-82.

Holiday, Billie, and William F. Duffy, Lady Sings the Blues (1956) (London, Penguin Press, 1992).

Kaplan, Cora, and Bill Schwarz, "Introduction: America and Beyond," in Cora Kaplan and Bill Schwarz (eds.), James Baldwin: America and Beyond (Ann Arbor, MI, University of Michigan, 2011), pp. 1-32. 
Kaplan, Cora, and Bill Schwarz (eds.), James Baldwin: America and Beyond (Ann Arbor, MI, University of Michigan, 2011).

McCann, Sean, Gumshoe America: Hard-Boiled Crime Fiction and the Rise and Fall of New Deal Liberalism (Durham, N.C., Duke University Press, 2000).

Muhammad, Ismail, "The Misunderstood Ghost of James Baldwin," Slate, 15 February 2017, www.slate.com/articles/arts/books/2017/02/how_critics_have_misunderstood_ james_baldwin_s_influence_on_today_s_great.html (accessed 23 June 2017).

Troupe, Quincy (ed.), James Baldwin: The Legacy (New York, Simon and Schuster, 1989).

Wall, Cheryl A., "Stranger at Home: James Baldwin on What It Means to Be an American," in Cora Kaplan and Bill Schwarz (eds.), James Baldwin: America and Beyond (Ann Arbor, MI, University of Michigan, 2011), pp. 35-52.

Wagner, Linda Martin, Ernest Hemingway: A Literary Life (London, Palgrave MacMillan, 2007).

\section{Contributor's Biography}

Robert J. Corber is William R. Kenan Jr. Professor in American Institutions and Values at Trinity College. He is the author and editor of several books, including most recently a scholarly edition of the queer modernist novel A Scarlet Pansy. 